Western University Scholarship@Western

Political Economy Research Group. Papers in

Political Economy

Economics Working Papers Archive

1990

Taking Interests Seriously

Doug Long

Follow this and additional works at: https://ir.lib.uwo.ca/economicsperg_ppe

Part of the Economics Commons

Citation of this paper:

Long, Doug. "Taking Interests Seriously." Political Economy Research Group. Papers in Political Economy, 5. London, ON: Department of Economics, University of Western Ontario (1990). 
POLITICAL ECONOMY

RESEARCH

GR O D P

\section{PAPERS IN POLITICAL ECONOMY}

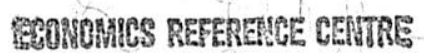

\section{FEB 152000}

\section{"Taking Interests Seriously"}

Doug Long

FPM. ONTA279

Paper No. 5

1001

70001

7001

5852001 
The Political Economy Research Group was established in the faculty of Social Science at the University of Western Ontario in 1988. Its purpose is to foster scholarship, teaching and interdisciplinary research in political economy, with a focus on:

1. the application of economic models and methods to the study of political processes and institutions,

2. the economic impact of political procèsses and institutions,

3. the influence of economic factors on the formation of públic policy and on institutional change,

4. the politics of economic policy making,

5. the political, social, and economic effects of public policy.

Co-directors:

Ronald Wintrobe (Economics)

Robert, Young:(Political Science)

\section{Board of Directors:}

Petèr Howitt (Economics)

B.B. Kymlicka (Pollitical Science) John N. MćDougall (Political Science)

Peter Neary (History).

John Whälleý (Economics)

\section{Staff:}

Jayne Dewar-

For further information:

Political Economy Research Group, Department of Economics,

Social Science Centre; London, Ontario, Canada N6A 5 C2 phone: (519) 661-3877

fax: (519) 661-3292 
ISSN : $\quad 1181-7151$

ISBN : $\quad 0-7714-1244-4$

\title{
TAKING INTERESTS SERIOUSLY
}

\author{
by \\ Doug Long \\ Department of Political Science \\ University of Western Ontario
}

March 1990 
Taking Interests Seriously

I. The predecessors of 'interest': 'virtue', 'law' and 'nature'.

As bases for theories of political and moral life, 'virtue' and 'right' have far longer pedigrees than 'interest'. At the beginning of the 'Western Tradition' the classical political philosophers built the polis on the basis of wisdom, truth and goodness (Plato), or of reason and nature (Aristotle). Stoic 'selfcommand', Epicurean pleasure, Ciceronian 'ius' or 'lex': all these were foundations for analyses of human action and political organization which situated these activities in a context fundamentally unlike that of interest-based modern theorizing. For theirs was the context constituted by natural law and natural right: a cosmological order which humankind had not made, but within which they must find their place. I shall argue that it was precisely when, and insofar as, faith in the existence of such an order was shaken and then abandoned that 'interest' was adopted as a central organizing concept in social and political theory.

The first great Christian overview of political thought, the work of st. Augustine, contained a little - noticed but prescient insight in the form of the observation that

'... many things must be done in correcting with a certain benevolent severity, even against their own wishes, men whose welfare rather than their wishes it is our duty to consult; and the Christian Scriptures have most unambiguously commended this virtue in a magistrate. "1

Here we find a glimmering of the modern concern with 'welfare' and the modern problem of the relation between wish-based, 'subjective' conceptions of interests and 'objective' (or perhaps more properi $y$ '

\footnotetext{
'Taking Interests Seriously' Pagel
} 
'third-party') conceptions of benefit or welfare. But of course for st. Augustine salvation was not merely something in which person: had an interest. It was the result of predestination and unearned Grace. Only much later, in the work of the theological utilitarians of the 18th century, would salvation be addressed in the language of 'interest'.

If st. Augustine began the period conventionally known as the 'Middle Ages' by reflecting on original sin, warning against the 'hell on earth' which could be created by indulgence in untrammeled passions and desires, and recommending that the magistrate pursue with 'benevolent severity' the 'welfare' of our eternal souls, it was st. Thomas Aquinas who provided the culminating synthesis of classical and medieval thought with his conception of four interrelated and harmonious levels of Law: the Eternal, the Divine, the Natural and the Human ${ }^{2}$. The quintessence of his vision is expressed in the famous dictum that Divine Grace perfects (rather than corrects, as in Augustinianism) nature ${ }^{3}$. Between the 4 th century B.C. and the 13th century A.D., then, political thinkers did not ask, in the modern spirit, what was 'in the interests' of individuals, nor how the interests of individuals might come into conflict or be brought into conformity with the public interest. They asked instead what was the nature of the order into which humanity was born, and what the place of the individual might be in that order.

II. The Discovery of 'interest'.

'Taking Interests Seriously' Page2 
When, then, did interests begin to be taken seriously in the history of Western political thought? Four inter-related developments seem to have contributed to - at any rate they accompanied - the emergence of an interest-based perspective on the individual and political society:

1. the recognition of commercial activity as both the prime matrix and nexus of human desires and a basis for fresh reasonings about the purpose and structure of socio-political life,

2. growing scepticism about traditional religious and philosophical arguments in support of political authority, 3. the secularization of social life and thought which accompanied 1. and 2. above, and

4. a major transformation of the methodological foundations of social and political thought, substituting a philosophy of action (often seen as analogous to Newtonian natural science) for the neo-classical cosmologies and medieval theologies: in short, the replacement of metaphysics by mechanics.

It is important to notice that the growth of commercial activity induced political thinkers in the early modern era to reconsider not only the nature of the human passions and desires, but also the nature of reason. The old natural law - based idea of reason as insight into a natural order of things was superseded with remarkable speed in the 17th and 18th centuries by a conception of reason as calculation - a development which, as we shall see, led to a widespread and almost indiscriminately 
enthusiastic reliance on prudence as the stuff of human motivation. Increasing employment of this view of human nature, couched in the language of 'interest', was made substantially more attractive by the steadily eroding strength of the old Neo-Platonic, Augustinian, Aristotelian and Thomistic accounts of human nature and political society. The language of prudence and interest, then, was the language of an emerging secular political theory in relation to which theology was, if not necessarily hostile, at least dispensible. This development seems to have begun in France, the country from which the idea of interest as political 'bed rock' was transported to England in the course of the 17th century.

Evidence of the crumbling of the old order and the birth of the new language of politics may be seen in the intense debates within the European Catholic Church in the 14th and 15th centuries over the relationship between sacred and secular authorities in the world. Much earlier than that, we have in the commercial oligarchy of Venice an example of a thoroughly commercial polity dating from the mid-eleventh century. By the time Machiavelli came to write his famous Discourses $(1513-7)$, it was quite appropriate for him to list Venice alongside Athens and Rome as a polity of true greatness ${ }^{4}$. But Machiavelli's political world of 'inquieto' and 'ambizione', of 'virtu', 'fortuna' and 'necessita', though it is a world of endless restlessness and unquenchable passions, is not yet understood as a world of conflicting 'interests'.

clearly some of the conditions which I have listed above for the emergence of a political theory focussed on 'interest' are 
present in the city states of the Italian Renaissance. Indeed it might be argued that in the works of thinkers such as Machiavelli and the Atheistic Venetian diplomat/cleric Paolo Sarpi ${ }^{5}$ all of them are present. Yet the actual self-conscious introduction of 'interest' into the Western political vocabulary actually takes place only as the result of a conjunction of French and English influences in the mid-seventeenth century. Eighteenth century English thought often reflects the influence of seventeenth century French thought in its recognition of the significance of the emergence of commercial society as a development fraught with consequences for political theory and practice. Antoine de Montchrétien, for example, well-known dramatist and sometime economic thinker, coined the phrase 'économie politique' in the title of his mercantilist work Traicté de l'oeconomie politique in $1615^{6}$. As a mercantilist, he sought to interest and involve the Crown in the economic management of the nation. But he also formulated something remarkably like the paradox which Anglophones so often treat as originating with Mandeville and Adam Smith - and as conveying the essence of a 'laissez-faire' position in political economy. Postulating 'a world in which each individual sets his sights on profit' and diligently pursues 'each little spark of utility', he asserted that

'... the most ordinary liaison between men, and their most frequent assembling together, depends on the help they provide for one another and the mutual offices they render to each other, in such a fashion that each is primarily motivated by
his individual profit, as he perceives it... Sounding particularly like Mandeville, he went on to observe that 
the 'lust for gain' of men of commerce is a like the venom of a 'viper' which contains its own antidote. The role of the crown ought to be, not to restrict commercial activity, but so to channel it as to derive public benefit from $i t^{8}$. It was with ideas quite like these, though derived from other 17th century French sources (Nicole and the Jansenists) that Mandeville made his notorious impact upon early 18 th century England. And the extent to which the utilitarianism of Bentham is anticipated both in substance and in style of presentation in the ouvrages de politique of the Abbe de Saint-Pierre, dating from the first quarter of the 18th century ${ }^{9}$, is startling: both men propose to use a calculus of pleasures and pains to determine the course of social behaviour most conducive to aggregate human happiness; both seek strong government to direct human activity along such a path; both see religion as a strategic instrument of secular rule aimed at secular ends; they even share a nearly impenetrable prose deformed by an addiction to neologisms! ${ }^{10}$

The significance for the development of a social theory of self-interest of the publication of Michel de Montaigne's Essais in 1580 is even greater than that of the works of Montchrétien and Saint-pierre, though its relevance to our theme here is at first less evident. But Montaigne's humanistic ruminations on the famous question 'que sais-je' were immensely influential in the two centuries following. Figures such as Hobbes, Mandeville, Hume and Montesquieu - all major theorizers of commercial society - openly acknowledged their indebtedness to Montaigne. For the form in which 
the concept of interest came to the fore in the period following Montaigne's work was that of 'self-interest', and Montaigne's was an unprecedentedly candid assessment of the private 'self' hidden behind a series of social, religious and political 'masks'. By persisting in his unique search for a 'self' situated in the context of worldly affairs, rather than in the context of a theological or philosophical cosmology, Montaigne made it possible for the 'self-interested self' to become for the first time the primary object of study for the social and political theorist. By relentlessly posing and reposing the basic question of how one ought to live in the wake of the materially and spiritually disastrous religious wars of 16 th century France, Montaigne eventually arrived at the distinctively modern conception of a self whose essence is agency. He single-handedly set in motion the process by which moral and political theory came to rest on a philosophy of motivation and action, rather than a metaphysic.

But we can be yet more specific than this about the process by which 'interest' assumed a central place in the vocabulary of English political thought in the seventeenth century, thanks to the careful attention given by my colleague J.A.W. Gunn of Queen's University to a work, now little known but then very popular, published in Paris in 1638 by the Duke de Rohan. It was entitled 'De L'Intérest des Princes et Éstates de la Chrestientè ${ }^{11}$. Gunn has convincingly shown that in the years following the prompt translation of this work into English a particular phrase coined by the Duc became the focus of remarkable attention. Rohan had

\footnotetext{
'Taking Interests Seriously' Page7
} 
stated it as a fundamental truth of political practice that 'I'interest seul ne peut jamais manquer' ${ }^{12}$. This was rendered into English as 'Interest will not lie', and this maxim in turn quickly became the vehicle for the emergence of 'interest' as 'the most fashionable political concept in the seventeenth century ${ }^{13}$. It is all the more remarkable that this should have happened despite the fact that the exact meaning of the phrase 'interest will not lie' was - and remains - extremely hard to establish with any real clarity. Along with its sister maxim, 'Interest Governs the World' ${ }^{14}$, 'interest will not lie' was employed in at least two kinds of usages which seem to me to be of great significance for the development of an interest-based language of politics in the modern era. What I call the first person usage of the maxim, the ancestor of the modern idea of subjective interest, is nicely captured in two examples given by Gunn. One, dating from 1655, states rather tautologically that 'if a man know what is his true interest, hee is undoubted true to it' ${ }^{15}$. The second, from the pen of Marchmont Nedham, author of 'Interest will not lie or a view of England's true interest' (1659), argues hopefully, if not to my mind persuasively, that

'... if a man state his own interest aright, and keep close by it, it will not lie to him or deceive him... nor suffer him to be misled or drawn aside by specious pretenses to serve the ends and purposes of other men. 16

There is more of enthusiasm than of rigour here. objective and subjective conceptions of interest are almost completely conflated: it is the agent who is charged with 'stating his own interest 
aright', but it is his interest in a vaguely disembodied sense that 'will not suffer him' to be manipulated by others. What is most interesting about these formulations is precisely their popularity in what we might anachronistically call an ideological sense. For some reason, individuals in large numbers were willing to commit themselves to the language of interest even though the slightest critical examination could have undermined the truth value of most of the maxims coined in that language. Might this not be because, in an era of growing scepticism and secularization and of dynamic commercial activity on an unprecedented scale, the term 'interest', with its long-standing French etymological linkages with commerce and its evident suitability to a context of practicality and action as opposed to spirituality and introspection, was strategically, pragmatically exactly what was needed to give a sense of order and limit to social and political life? To Montaigne's 'Que sais-je?', the men of commerce answered 'Interest will not lie.'.

'Interest' was thus demystified. Where earlier it had been common to speak of interest as attaching in abstract and/or esoteric ways to Princes and Kingdoms ${ }^{17}$, now it was understood that every man (or even everyman - though it would be distorting the case, in this instance, to insert a gender neutral noun) had his self-interest, and that the sense of self-interest was as central to a man's social and political activity as the law of nature was held to be by Locke in his second Treatise. It is perhaps worth noting that Locke is not a pillar of but an exception to the tradition we are mapping here. The genealogy of interest-based

'Taking Interests Seriously' 
political thought after 1638 runs from Hobbes to Mandeville to Hume to Smith to Rousseau to Bentham to J.S. Mill. The centrality of theology to Locke's thought is reflected in his reliance, despite his appreciation of the importance of money, property and exchange in socio-political life, on the language of natural law and natural right in his moral and political theory.

The first person usage of 'interest' developed in tandem with what I call the third person usage. The latter, while in some ways less edifying than the former, was far less tautological and had more evident implications for politics. Marchmont Nedham's book is again the source:

'... if you can apprehend wherein a man's interest to any particular game on foot doth consist, you may surely know, if the man be prudent, whereabout to have him, that is, how to judge of his design. 18

As Albert 0 . Hirschman has persuasively argued in his brilliantly suggestive book The Passions and the Interests, the charm of 'interest' here is that it domesticates the passions ${ }^{19}$. The Duc de Rohan had distinguished, in 1638, between passions, which he saw as founded on impulse, and interest, which he saw as founded on calculation ${ }^{20}$. Among the examples of this view given by Gunn is a sermon preached before the English House of Commons in 1647 which contained the advice: 'beware of passion in your interests ${ }^{21}$. And fear of chaotic passions is nicely combined with gratitude for the predictability and, in a consequentialist sense, rationality of self-interested behaviour in an observation dating from 1667:

'to surmise the acting of multitudes, contrary to their own interests $\ldots$ is to take away all assurance out of human 
Thus rapidly did the conception of self-interested behaviour become the source of 'all assurance' in 'human affairs' and the means by which men might confidently 'judge of the designs' of other men in 'any particular game on foot' in the social or political sphere. Each of the usages of 'interest' which I have identified relies for its appeal on an evident assumption that interest, which had for some time previous to this period been taken to refer to the arcana imperii, the mysteries of princes and priests, was now taken to be a reified entity somehow borne by every independent and rational property-holder in the commonwealth. It was partly for this reason that the slogan 'interest will not lie' was strongly associated with the whigs, and its influence provoked near despair in a High Tory writer sich as John Dryden, who attacked it in his poem The Medall in 1682. The world, he lamented, had become 'o'erstocked with prudent men' ${ }^{23}$. The 'Almighty Crowd' was no longer restrained by deference to 'Faith', 'Reason' or 'eternal truths'24. He attacked the Whigs, and particularly Lord Shaftsbury, for 'preaching to the Crowd'. Shaftsbury's Whiggism, he protested,

'Maintains the Multitude can never err

And sets the People in the Papal chair. The reason's obvious; INTEREST NEVER LYES;

The most have still their int'rest in their eyes;

The pow' $r$ is always theirs, and pow'r is ever wise. 25

The plaintive cries of the Tory Dryden were in vain: the belief that 'interest will not lie' soon grew into the assertion that 'Interest Governs the World', and the Tory complaint that 'the word "interest" is now the only idol that men fall down and worship'26 
served only to confirm, and not to retard, this development.

III. Politics and 'self-interest': from Hobbes to Utilitarianism.

I now wish to sketch the intellectual chain of development which links (1) the Duc de Rohan's recognition that interest is based on 'calculation', and (2) Dryden's protesting recognition that the behaviour-shaping principle which results from this calculation is a principle of 'prudence' with (3) the moral and political system which most exhaustively played out the implications of these insights, Bentham's utilitarianism. For the views of Rohan and Dryden (leaving aside Saint-Pierre) are but harbingers of the utilitarian calculus, and their emphasis on prudence but an intimation of the absolute sovereignty which Bentham was to claim for the Principle of Utility over the fields of morals and legislation.

Hobbes, as was so often the case, saw very early and very clearly that the new role of 'Morall and civill science' in the age of commerce and rational self-interest would be to induce men to see beyond their wishes to their welfare:

'... All men are by nature provided of notable multiplying glasses, (that is their Passions and self-love,) through which, every little payment appeareth a great grievance; but are destitute of those prospective glasses, (namely Morall and Civill Science,) to see a farre off the miseries that hang over them, and cannot without such payments be avoided. 27

As my colleague David Wootton has pointed out,

'Hobbes ... secularizes the notion of a God-fearing society, making God unnecessary for the establishment of order, at least among people who are capable of rationally calculating their own interests. 28 
Hobbes was far from the most cynical or morally pessimistic of theorists on this score. He held out some hope that the study of

'morall and civvil science' might acquaint men with the necessity of paying, through submission to an absolute sovereign, the price of freedom. Fifty years after Leviathan, however, traditional moral and political sensibilities were shocked by the assertion in Bernard Mandeville's Fable of the Bees that the immense and irresistible 'Publick Benefits' of commercial society were based on the 'Private Vices' of vain and self-centred individuals whose 'crimes conspired to make them great' ${ }^{29}$. This seemed to some, among them Adam Smith, tantamount to declaring life in commercial society a Hobbesian war of each against all $1^{30}$. But Mandeville was essentially a gad-fly. He expounded no systematic moral or political doctrine of rational self-interest. It was precisely for that reason reason that he was bitterly attacked by smith in the latter's Theory of Moral sentiments (1757) for putting forward a 'licentious' system of morals, one which effectively annihilated the distinction between vice and virtue ${ }^{31}$. It was one of Smith's main objectives in TMS to show that commercial activity and ethically sociable behaviour had a common root in rational selfinterest. A society based solely on a shared recognition of intersecting economic self-interests would, Smith asserted, be 'less happy and agreeable' than one based on mutual 'love ... gratitude ... friendship, and esteem', but

'Society may subsist among different men, as among different merchants, from a sense of its utility, without any mutual love or affection ... it may still be upheld by a mercenary exchange of good offices according to an agreed valuation. ${ }^{32}$

'Taking Interests Seriously' Page13 
It was in this context that smith made his famous observation that

'It is not from the benevolence of the butcher, the brewer, or the baker, that we expect our dinner, but from their regard to their own interest. We address ourselves, not to their humanity but to their self-love. 133

Adam Smith's exposition of the role of utility and selfinterest in the formation and functioning of civil and political society was in fact more muted, more mitigated by a belief in the sociability of man derived from the intellectual tradition of civic humanism, than was the treatment given to these subjects by his dear friend and direct predecessor David Hume. In his Treatise of Human Nature, Hume argued that the very foundation of civil society was constituted by men's shared historical experience of the evident public and private utility of the basic social conventions of justice and property. Over time, experience of utility produced a crucial convergence, neither virtuous nor vicious but simply expedient, of judgments as to the interest men had in sustaining society. Citizens could be relied upon to 'pay their creditors, perform their promises, and abstain from ... justice of every kind', but this was not because they would naturally look to the 'public interest':

'That is a motive too remote and too sublime to affect the generality of mankind, and operate with any force in actions so contrary to private interest as are frequently those of justice and common honesty. ${ }^{34}$

Hume does assert that a 'general sense of common interest' enables men to agreee to 'regulate their conduct by certain rules', but this is a sense of overlapping self-interests, not a self- 
abnegating commitment to a 'higher' public good ${ }^{35}$. The acceptance of political obligation results only from the redirection, not the denial, of self-interest:

'There is no passion ... capable of controlling the interested affection, but the very affection itself, by an alteration of its direction. Now this alteration must take place upon the least reflection; since 'tis evident, that the passion is much better satisfied by its restraint than by its liberty ...136

With remarkable clarity and aggressiveness, Hume goes on to assert that henceforth the 'origin of society' is to be explained solely by reference to 'the passion of self-interest', and that traditional moral theory is irrelevant to the matter:

'The question ... concerning the wickedness or goodness of human nature, enters not in the least into that other question concerning the origin of society ... For whether the passion of self-interest be esteemed virtuous or vicious, 'tis all a case; since itself alone restrains it: So that if it be virtuous, men become social by their virtue; if vicious, their
vice has the same effect. 37 .

Thus Hume came to take 'interest' very seriously indeed as the fuondation of social and political theory and practice. His philosophical (and theological) scepticism led him to apply an 'experimental method to moral subjects ${ }^{38}$, and the result was the driving of a wedge between moral theory proper, which was concerned with human character as manifested in the aesthetic qualities of human action (such as nobility or propriety), and socio-political theory, concerned with the necessities and conveniences of life in a polity. In Hume's political thought interest, prudence, expedience and utility were clearly but only informally linked. They were soon, however, to be welded together into a single neoNewtonian science of man and society by a man who claimed that his 
synthesis was partly inspired by a reading of Hume's Treatise: Jeremy Bentham.

In 1776 Adam Smith published the Wealth of Nations, David Hume died, and Jeremy Bentham published his first, and some would say his only readable, work, the Fragment on Government. In the Fragment, Bentham said that when he read the third book of Hume's Treatise, he felt as though scales had fallen from his eyes ${ }^{39}$. It must be pointed out that what Bentham claimed to find in the Treatise was rather different from what Hume had meant to put there, but for our purposes the simple fact of a verifiable influence of Hume on Bentham in terms of utility is important. In consequence of his reliance on the 'passion of self-interest' as the basis of civil society, Hume had argued that subjects constantly resorted to a 'principle of public utility' in their day-to-day activities ${ }^{40}$. struck by this insight, and combining it with what he had learned from the jurisprudence of Beccaria and the conception of a monolithic science of legislation and morality entertained in De L'Esprit, the work of the French philosophe Helvetius ${ }^{41}$, Bentham enthusiastically proclaimed that the sciences of morals and legislation were alike founded solely on a single 'Principle of Utility', and that this principle in turn was the expression of the simple facts of hedonism: that pleasure and pain are our 'sovereign masters', governing us in all that we do as well as dictating what we ought to $\mathrm{do}^{42}$. This was, of course, to ignore the fact that Hume had carefully referred to utility in the context of moral theory proper (as distinct from political theory) as a 
'circumstance', not a principle. ${ }^{43}$ Both Hume and Smith, however, had realized that the politics of self-interest tended in practice to be the politics of utility. Smith, like Hume, had recognized a 'principle of utility' as the basis of Whig politics ${ }^{44}$. But Bentham alone coined the term (he said it came to him in a dream) 'Utilitarian'45. And by the same token Bentham took interest more seriously, in the sense of giving it a more fundamental place in his systematic moral and political theory, than had any thinker before him. His utilitarian system might well have been inspired by the 17 th century saying that 'Interest Governs the World'.

Between 1776, when he made his fulsome public obeiscence to the utilitarian Hume-who-never-was, and 1789 Bentham laboured with obsessive determination to complete the structure of his system of 'Censorial Jurisprudence ${ }^{46}$. It was partly a repudiation of the jurisprudence of Blackstone, but it was also much more than that. Bentham defined jurisprudence as the study of politics and government, and critical jurisprudence as the study of politics and government as it ought to be $e^{47}$. His utilitarian critical jurisprudence, then, was in effect a political theory, presupposing a moral theory, founded on the notion of man's natural interest in happiness.

In his Introduction to the Principles of Morals and Legislation, almost entirely written in 1780-2 but published in 1789, Bentham presented 'interest' as a sort of intellectual bedrock: a concept entirely sui generis, directly linked to pleasure and pain and reducible to no simpler or more basic 
components $^{48}$. Whereas some modes of political and social thought have always felt it necessary to derive legitimate interests from rights, Bentham's analysis unhesitatingly reduced rights to interests - or else, more famously, to 'nonsense upon stilts' ${ }^{49}$. Bentham understood rights of every kind as components of a network or web of reciprocal privileges and obligations, liberties and restraints: a 'fabric of felicity' woven 'by the hands of reason and of law $^{150}$. Viewed in this way a right was nothing more than an abstraction: a useful but 'fictitious' label attached for some strategic purpose to certain species of interests. 'Interest' as Bentham saw it was a fundamental and universal category within which 'right' could be swallowed whole: persons could not always be said to have a right to happiness, but they could always be said to have an interest in it:

'Such things, such situations and such events mankind may be said to be interested in, as tend to encrease their Happiness or Unhappiness. ${ }^{51}$

In Bentham's hands political and social theory became a systematic search, involving an endlessly complex apparatus of definitions, classifications and measurements, for the basic 'facts' of human existence. All mankind had an interest in knowing such facts, for information about the impact (or anticipated impact) of various 'situations' and 'events' on human happiness was the sine qua non of successful legislation and indeed of successful social life. Such factual knowledge was the only acceptable basis, in Bentham's eyes, for a scientific treatment of basic human interests from both first-person and third-person points of view. 
This was not to be confused with an account of basic or natural rights. Bentham clearly acknowledged that there was a place in such a science for the concept of 'rights', but he was scathing about the rhetorical vaccuity of standard defences of rights discourse in his day:

'Talk of right - say a man has a right to such a thing in such a case, and we have no matter of fact to encumber ourselves with - when you have said he has a right - insist upon it: ... all proof is needless. The business is thus settled in a trice by the help of a convenient word or two, and without the pains

Bentham aimed to replace the subjectivity of rights discourse based on 'sentiment'with an interest-based discourse based on 'matters of [objective] fact' and on 'calculation':

'Utilitarianism, working by calculation, is consistent and solicitous benificence. Sentimentalism, in so far as independent of utilitarianism, is in effect a mask for selfishness or malignity, or both for despotism, intolerance,

IV. 'Interest' versus 'Right': Bentham and the French Revolution. If in 17th century Whiggism we found a blossoming of enthusiasm for 'interest' but no rigorous or critical analysis of it, in Bentham's 18th century utilitarianism we find a more analytically interesting way of taking interests seriously. And not only did Bentham try to construct in his utilitarian system a science of interests, but he also applied that science to the world of political practice in his long warfare with 'sinister interests' in British society and politics in his day. His disgust at the predominant influence of elite ecclesiastical, legal and political 
interest groups in contemporary public life was one of the key factors which led him to ally himself with James Mill in the latter part of his life. Bentham the utilitarian became Bentham the 'philosophcial radical' when he decided that the promotion of a more democratic franchise was the only way to generate governments in Whitehall which would pursue a notion of the public interest compatible with the interests of the majority of responsible, property - holding males in the populace. It was not, however, in the course of laying out (as he did very late in life) a 'Constitutional Code' for Great Britain that Bentham gave his most reflective and principled defence of an interest-based political theory. In fact the problems of reconciling the self-interested nature of man with the need to identify and promote a public interest are not particularly clearly dealt with in Bentham's applied political writings. It was the challenge to his theory itself, to the principles of his 'critical jurisprudence', posed by foreign events that prompted Bentham's most analytically interesting comments on interest-based and rights-based political theories. And the 'foreign events' involved were those constituting the French Revolution.

We must recall at this point that in 1789 Bentham, then 41 years old and seeking with increasing anxiety to win public attention for his elaborate, iconoclastic and painstakingly constructed system of morals and legislation, was in the very act of publishing - to no public acclaim at all - his Introduction to the Principles of Morals and Legislation, when all the world's 'Taking Interests Seriously' Page20 
attention was suddenly seized by events in France. At first he too was excited, visualizing the French asking his advice on all kinds of problems of reform and reconstitution for the French state. Although he was, ironically, made an honorary citizen of France ${ }^{54}$, as time went by he became more and more disillusioned and finally disgusted by the principle which guided - or rather failed to guide - the actions of what he came to call the 'French Pandemonians'55. By about 1795 he was at work on a project whose title makes clear that he had, to his own satisfaction, identified the root of all evil in French revolutionary political thought:

'Pestilential Nonsense unmasked; or an Anatomy of the First French Declaration of Rights Ao 1791; and of all other Declarations, actual or possible, of pretended Natural Rights in contradistinction /opposition/ to legal ones. 156

Bentham briefly contemplated an alternative title for this work, to wit:

'No French Nonsense: or a Cross-buttock for the first Declaration of Rights, together with a kick of the A-- for the Second ... is by a practitioner of the old English Art of In this somewhat bizarre way the issue was joined between legal positivism, the natural companion of an interest-based political theory, and natural rights. This Benthamic work was published only posthumously, as Anarchical Fallacies ${ }^{58}$, but as Professor H.L.A. Hart has observed, it contains 'Bentham's most comprehensive and detailed criticisms' of the doctrine of natural rights. ${ }^{59}$

In Anarchical Fallacies Bentham offered two explanations for the the popularity and seductiveness of rights discourse. The first of these focussed on the fraudulent reification of rights.:

\footnotetext{
'Taking Interests Seriously' Page2l
} 
'In its adjective shape, [the word right] is as innocent as a dove: it breathes nothing but morality and peace. It is in this shape that, passing in at the heart, it gets possession of the understanding: - it then assumes its substantive shape, and joining itself to a band of suitable associates, sets up the banner of insurrection, anarchy and lawless violence. $160^{\circ}$

The reification of 'right' confers on what is actually a thoroughly subjective judgment as to 'rightness' an illusion of objectivity, so that persons who might well recognize the difficulty in knowing exactly what was the right thing to do in a complex situation could still find it all too easy to demand that, what ever was done, their rights should not be violated. The second source of fraudulent rights discourse identified by Bentham was exactly the source we should expect a legal positivist to spot: the idea of natural law -

'Right, the substantive right, is the child of law: from real laws come real rights; but from imaginary laws, from laws of nature, fancied and invented by poets, rhetoricians, and dealers in moral and intellectual poisons, come imaginary rights, a bastard brood of monsters ... 161

Bentham offered his Anarchical Fallacies as an 'antidote to French poisons', a 'preservative for the understanding and the heart against the fascination of sounds ${ }^{62}$. He saw the problem as one of language: 'an original vice in the structure of language' had given birth to loose talk of rights. 'The language of plain strong sense', he lamented, 'is difficult to learn; the language of smooth nonsense is easy and familiar. ${ }^{63}$

Anarchical Fallacies abounds in vivid and inventive attacks on rights discourse in general and declarations of rights in particular. But the logic of Bentham's critique is consistent and

\footnotetext{
'Taking Interests Seriously' Page22
} 
simple: 'real rights' are the children of 'real laws'. Laws in turn are expressions of calculations of the interests of the individuals and groups which make up a given jurisdiction. Rights are thus not the grounds but the symptoms of our most fundamental interests. In the field of legislation, when 'give me my rights' means anything determinate, it means 'give proper weight to my interests'. An honest and beneficent legislator can and should promise no more. When J.S. Mill proposed to take as the foundation of his political theory 'utility in the largest sense, grounded on the permanent interests of $\operatorname{man}$ as a progressive being ${ }^{64}$, he was implicitly endorsing Bentham's position by avoiding recourse to the idea of man's 'natural rights' as constitutive of his progressive nature.

V. 'Interest' and 'Right' in contemporary political discourse: subjectivity, objectivity and inter-subjectivity.

The encounter between legal positivism and natural rights theory constituted by Bentham's response to the French Declaration of the Rights of Man brings to light, both historically and conceptually, a clear and important contrast between two modern approaches to the theory and practice of politics and policymaking. From that day to this, interest-based and rights-based strains of discourse have been available, and have been used, to establish political priorities in states which are usually said to be (1) dedicated to the pursuit of 'the public interest' or 'the national interest' and (2) committed, at the same time, to the respecting of individual, group, or human 'rights'. Rights 
discourse has remained the 'easy and familiar' way of articulating popular concerns on many issues, but no one will deny that the articulating, weighing and organizing of interests constitutes much of the substance of day-to-day politics. Hard cases arise when it becomes necessary to deal with claims couched in the language of rights which may on close examination turn out to be assertions of strong interest (when does an intensely felt 'need' constitute a right, and when not?), or on the other hand to justify policy decisions by reference to a national or public interest which is perceived as infringing on rights. Political theory and practice in the present and the foreseeable future could benefit from taking a closer look than we have hitherto been inclined to do at the 'mix' of these kinds of claims and policy justifications in modern liberal-democracies.

our political way of life simply is a byzantine interweaving of interest-based and rights-based activities, and the better we can come to understand that fact, the better off we will be. How much of the time, politically, do we wish to say 'Rights are trumps', and leave it at that? 'Rights are trumps' can be a dangerous doctrine, as anyone involved in the attempt to graft a Charter of Rights and Freedoms on to the stem of a political tradition involving a substantial common law component will confirm. On the other hand, how far are we willing to go in the direction of saying that all competing political claims (including the ones with substantial moral content) are negotiable, that nothing in politics is absolutely 'right'? 
As a case in point, to what extent should the claims of women today for more equitable political treatment and a more appropriate portion of real political power be construed as expressions of an interest common to all women, and to what extent as demands for women's rights? The feminist who thinks in terms of interests is likely, I submit, to be more amenable to incremental change in the position of women in society, while the women's rights advocate is logically compelled to strive for radical change at a stroke, or at least is prevented from seeing incremental change as significant except as some fraction of a required radical transformation of social relations.

Of course, one can employ both strategies, but presumably not both at once, and it will be helpful to be as clear as possible about what criteria are employed in locating an issue in one category as opposed to the other. If rights are to be trumps, that is a very good reason for restraint and selectivity in invoking the authority of rights discourse in defining and settling disputes. Indiscriminate use of a limited supply of 'trump cards' is bad strategy, and any attempt to claim 'trumps' status for cards of another suit reduces the game to a shambles. In a game of 'no trumps', at least the value of each card in the deck is as it appears to be! In a sense, politics should only be compared to a 'no trumps' game, for where trumps are invoked, there is an end of political mediation, negotiation, conciliation: the 'right thing' must be done. Moral or religious or ideological considerations have supplanted strictly political ones. Rights discourse tends to 
define the limits of the political realm - the boundary beyond which political processes become pure instrumentalities in the service of 'higher' principles. Interests are the genuine stuff of politics, and taking interests seriously is what 'intramural' political contestation is about. The tendency to make rights discourse the easy and familiar language of politics is symptomatic of the well-known tendency of modern political ideologies to become 'secular religions'. What would happen if we attempted to become more comfortable with and accustomed to Bentham's language of 'plain strong sense', the language of interests? Would this necessarily lead to the increasing violation of 'real' rights? would this inevitably result in moral barbarism in politics?

I do not think so, but it would be hard to reach a firm conclusion in the matter without addressing the problem with which I now want to conclude this discussion: the problem of subjectivity versus objectivity in relation to interests. The tendency of modern ideological argument has been to treat subjective assertions of interest as weak sisters to rights claims. And the criterion used, both in Marxist and in liberal-democratic thought, to distinguish strong from weak interest claims has been 'objectivity'. Just as Marxists have been willing to distingush subjective 'false' consciousness from objective revolutionary consciousness, so the New Right have been more than willing to assert that acquisitive, utility-maximizing behaviour is simply 'natural to Man' and expressive of an objective, not merely a subjective, sense of what is in the interests of individuals. Both ideological extremes,

\footnotetext{
'Taking Interests Seriously' Page26
} 
unwilling to settle for the modest task of serving the interests of individuals as subjectively understood by those individuals, insist on liberating them and/or giving them their rights - which very often seems to mean, in the end, promoting their welfare, to secularize St. Augustine's dictum, at the expense of their wishes.

But a politics which takes interests seriously need not objectify interests in the theoretical sense in which our dominat ideologies have tended to do so. Indeed it ought not to do so. For when interests which have been declared objective in this sense clash, armaggedon ensues. This is because the ideological treatment of interests exhibits too much of a residual tendency, derived presumably from the longer history, the rhetorical attractiveness, the familiarity and the simplicity of rights discourse, to take interests seriously by treating them like rights. Thus for example strong or fundamental interests are reified like rights, and this encourages claimants to think in all-or-nothing terms rather than in pragmatic terms about their political treatment. More importantly, the 'objectivity' claimed for basic interests is expressed either through reification or by recourse to the old metaphysical language of universality, transcendance or immanence. Marxist ideas of the rights of workers and New Right notions of the rights of entrepreneurs are, ironically, cast in the language of pre-commercial natural rights discourse. A review, such as I have attempted to sketch here, of the origins and nature of interestbased normative political theory suggests that an appropriate criterion for the seriousness of interest-based claims would emerge

\footnotetext{
'Taking Interests Seriously' Page27
} 
if we relied not so much on a black/white, subjective/objective distinction as on a sliding scale of inter-subjectivity: a pragmatic and aggregative measurement of the extent and intensity of interests, avoiding recourse to metaphysical notions of 'nature' or 'virtue'. It will be argued, I expect, that such a criterion of the seriousness of interests is relativistic. So be it. Is this worse than the endless variety of ways in which theorists have (subjectively) situated 'self-interest' on a spectrum of possibilities ranging from solipsism and narcissism at one extreme to self-effacing altruism at the other? This exercise has accomplished little except to show the impossibility of pure narcissism or pure altruism as limiting cases, and to leave the real question of the relationship between rational self-interest and socio-political obligation as open as it had been before.

There is much to be done in the day-to-day life of every polity, whatever its ideological colouration, that involves no more than the provision of an essential framework for the mediation of negotiable claims among citizens and groups. Insofar as politics is not secularized religion but consensual societal practice, the language of plain strong sense, the language of interest, is at its very marrow. The present moment, when ideological tensions are at least momentarily reduced in the world, provides an opportunity to return to the modest but essential political task of enabling individuals to pursue their interests as they see them. And a moment's reflection makes it clear that acceptance of the intersubjective nature of interests is not nearly as threatening to the 
stability of political regimes and cultures as would be a blanket proclamation of the subjectivity of all rights claims. So why not dedicate an enhanced share of our political energies to the promotion of self-interested behaviour through the careful maintenance of civil liberties, impartial legal process and other essential political instrumentalities? Interests and rights are not always related as in a zero-sum game. No threat to rights, and perhaps substantial gains in freedom, could result from a political resolution to take interests seriously. This is but a modest conception of what politics is about, but the consequences of losing sight of it amid the drama and catharsis of the struggle for rights of one kind or another are surely worth avoiding.

1.Bigongiari, D. (ed.), The Political Writings of st. Augustine, Regnery Gateway, 1988, p. 178 .

2. See Baumgarth, W.P., \& R.J. Regan, S.J. (eds.), Saint Thomas Aquinas: On Law, Morality, and Politics, Hackett, $1988, \mathrm{pp} .17$ 29.

3. See Sigmund, P.E. (ed.), st. Thomas Aquinas on Politics and Ethics, Norton Critical Editions, 1988, ed's intro. p. xix.

4. See Gilbert, A. (tr.), Machiavelli: the Chief works and others, Duke U.P., 1965, 3 Vols., Vol. I: Discourses on the First Decade of Titus Livius, Book I, Chapters 1 (p. 192) and 5 (pp. 204-5).

5.I have in mind here the remarkable life of sarpi written by my erstwhile colleague David Wootton: Paolo Sarpi: between renaissance and enlightenment, Cambridge U.P., 1983.

6.See Keohane, N.0., Philosophy and the state in France: the Renaissance to the Enlightenment, Princeton U.P., 1980, pp. 163-8.

7. Keohane, op. cit., 164.

8. Ibid, 167 .

9. Keohane, op. cit., 362-76.

10. Ibid, pp. 365-8.

'Taking Interests Seriously' Page29 
11.See Gunn, J.A.W., "Interest will Not Lie": A SeventeenthCentury Political Maxim', Journal of the History of Ideas, Vol. XXIX, Oct. - Dec. 1968, pp. 551-64, at p. 553 \& fn. 12 .

12. Ibid.

13. Ibid, p. 551 .

14. Ibid, p. 559 \& fn, 37.

15. Charles Herle, 'late the Prolocutor of the Westminster Asembly of Divines', in his work Wisdomes Tripos (1655): cited in Gunn, op. cit., p. 556..

16. Cited in Gunn, op. cit., p. [?].

17. See, for example, Gunn, op. cit., p. 552 \& fn. 3,553 \& fn. 9, 556 .

18. Marchmont Nedham, 'Interest will Not lie...', cited in Gunn, op. cit., p. 557.

19.Hirschman, A.O., The Passions and the Interests: Political Arguments for Capitalism before its Triumph, Princeton U.P., 1977, pp. 31-42.

20. See Gunn, op. cit., p. 558 .

21. The preacher was one Thomas Manton; Gunn, op. cit., p. 558 \& fn. 31 .

22. Ibid, p. 559 \& fn. 35.

23. 'Some think the Fools were most, as times went then;

But now the World's o'rstock'd with prudent men.'

From 'The Medall: a Satyre Against Sedition - Epistle to the Whigs', in Kinsley, J. (ed.), The Poems of John Dryden, Oxford, Clarendon Press, 1958, 2 Vols., Vol. 1, pp. 250-61; at p. 256, lines $101-2$.

24. Ibid, lines $91-4$.

25. Ibid, lines $82-90$.

26. Gunn, op. cit., p. 556 \& fn. 22 .

27. Macpherson, C.B. (ed.), Leviathan, Pelican Classics, Bk. II, Ch. 18, p. 239.

28. Wootton, D., Divine Right and Democracy, OUP, 1987 [?], 'Introduction', p. 61 .

'Taking Interests Seriously' Page30 
29. Kaye, F.B. (ed.), The Fable of the Bees, or Private Vices, Publick Benefits, with a Commentary Critical, Historical, and Explanatory by F. B. Kaye; 1st pub. Oxford, Clarendon Press, 1924; new ed'n in two vols. Liberty classics, Indianapolis, 1988; vol. 1, p. 24 .

30. Adam Smith, The Theory of Moral Sentiments, ed. A.L. Macfie \& D. D. Raphael, Oxford, Clarendon Press, 1976, Glasgow Edition of the Works and Correspondence of Adam Smith; Part VII, section ii, Chapter 4, pp. 306-14: Smith did allow (313) that Mandeville's argument 'in some respects bordered on the truth', but could not accept Mandeville's failure to distinguish 'between real prudence and short-sighted folly or precipitate rashness'(306).

31. Ibid, esp. at pp. $306 \& 308$.

32. Smith, Moral Sentiments, Part II, section ii, Chapter 3, pp. 85-6.

33. Adam Smith, An Inquiry into the Nature and Causes of the Wealth of Nations, ed. R. H. Campbell, A. S. Skinner \& W. B. Todd, Glasgow Edition of the Works ...., Oxford, Clarendon Press, 1979; Book I, Chapter II, pp. 26-7.

34.David Hume, A Treatise of Human Nature, ed. E.C. Mossner, Penguin Classics, 1985; Book III, Part II, Section I, p. 533 .

35. Ibid, Book III, Part II, section II, p. 541.

36. Ibid, p. 544 .

37. Ibid.

38. The Treatise of Human Nature was sub-titled 'An Attempt to introduce the experimental Method of Reasoning into Moral Subjects'.

39. See A Comment on the commentaries and a Fragment on Government, ed. J. H. Burns \& H. L. A. Hart, Collected Works of Jeremy Bentham, Athlone Press, 1977; Fragment, Chap. I, para. 36, fn. v, part 1, pp. 439-40.

40. Hume's Enquiries concerning Human Understanding and concerning the Principles of Morals, reprinted from the 1777 edition, intro. L. A. Selby-Bigge, 3rd edition revised P. H. Nidditch, oxford, Clarendon Press, 1975; see ' ... concerning the Principles of Morals', section III, part II, p. 203.

41. In De L'Esprit Helvetius had asserted that

'As the physical world is ruled by the laws of movement so is

the moral universe ruled by laws of interest.'

cited in Hirschman, The Passions and the Interests, p. 43.

'Taking Interests Seriously' Page31 
42. See Bentham, An Introduction to the Principles of Morals and Legislation, ed. J. H. Burns \& H. L. A. Hart, Collected Works of Bentham, Athlone Press, 1970, Chapter I para. 1, p. 11.

43. Hume, An Enquiry Concerning the Principles of Morals, in Hume's Enquiries, 3rd edition rev. P. Nidditch, p. 231.

44. See Adam Smith: Lectures on Jurisprudence, ed. R. L. Meek, D. D. Raphael \& P. G. Stein, Glasgow edition, Oxford, 1978, p. 319.

45. I dreamt t'other night that I was a founder of a sect ... a personage of great sanctity and importance. It was called the sect of the utilitarians.'

Bentham Manuscripts, University College London Collection, Box CLXIX (169), p. 79: headed 'Dream'; probable dating 1781.

46.See Long, D., 'Censorial Jurisprudence and Political Radicalism', in The Bentham Newsletter, No. 12, June 1988, pp. 423.

47. Ibid, pp. 16-7.

48. Bentham, Introduction to... Morals and Legislation, ed. Burns \& Hart, Chap. I, para. 5 \& fn. c, p. 12.

49.See Harrison, R., Bentham, London, Routledge, 1983, Chapter 4, p. $77 f f$.

50. Bentham, Introduction, Ch. I, para. 1, p. 11 .

51.Manuscripts of Jeremy Bentham, University College London Collection, Box LXIX, p. 150, side 2, headed 'P.P.I. [Preparatory Principles Inserenda] \#599'.

52 . Ibid, Box LXIX (69), pp. 6-7, headed 'Crit[ical] Jur[isprudence] Crim[inal]; marginal heading 'Right Civil founded on Natural - the notion exploded'.

53. See Bentham, 'A Table of the springs of Action: Marginals Added Observations', in Goldworth, A. (ed.), Deontology: together with A Table of the springs of Action and the Article on Utilitarianism, Collected Works, Oxford, 1983, p. 35 .

54. See Jean Marie Roland de la Platiere, Le Ministre de l'Interieur de la République Françoise, to Jeremy Bentham, 10 October 1792, in The Correspondence of Jeremy Bentham, Vol. 4, ed. A. T. Milne, Collected Works, Athlone Press, 1981, \#870, p. 398 .

55. See Bentham to the Duc de Liancourt, 11 October 1795, in Correspondence, ed. Milne, Vol. 5, \#1085, p. 161.

'Taking Interests Seriously'

Page 32 
56. See Correspondence, Vol. VI, ed. J. R. Dinwiddy, oxford, Clarendon Press, 1984, \#1636 to Wm. Cobbett, 30 June 1801, p. 408n.

57. See Bentham Manuscripts, U.C.L. Collection, Box $\operatorname{CVIII~(108),~p.~}$ 114 .

58.See Bowring, J. (ed.), The Works of Jeremy Bentham, first published 1838-43, reproduced by Russell \& Russell, New York, 1962, Vol. II, pp. $489-534$.

59.Hart, H. L. A., Essays on Bentham: Jurisprudence and Political Theory, Oxford, clarendon Press, 1982, Chap. IV at p. 79.

60. Ibid, p. 523, col. 2 .

61. Ibid, col. 1.

62. Ibid.

63. Ibid, p. 524, col. 1 .

64.J. S. Mill, on Liberty, ed. J. M. Robson, U. of Toronto Press, 1977 (Collected Works of John stuart Mill, Vol. XVIII), p. 224. 